\title{
Caspase Activation in Hair Cells of the Mouse Utricle Exposed to Neomycin
}

\author{
Lisa L. Cunningham, Alan G. Cheng, and Edwin W Rubel \\ Virginia Merrill Bloedel Hearing Research Center and Department of Otolaryngology-Head and Neck Surgery, University of \\ Washington, Seattle, Washington 98195-7293
}

\begin{abstract}
Aminoglycoside exposure results in the apoptotic destruction of auditory and vestibular hair cells. This ototoxic hair cell death is prevented by broad-spectrum caspase inhibition. We have used in situ substrate detection, immunohistochemistry, and specific caspase inhibitors to determine which caspases are activated in the hair cells of the adult mouse utricle in response to neomycin exposure in vitro. In addition, we have examined the hierarchy of caspase activation. Our data indicate that both upstream caspase-8 and upstream caspase- 9 , as well as downstream caspase- 3 are activated in hair cells exposed to
\end{abstract}

Mechanoreceptive auditory and vestibular hair cells are sensitive to damage from a variety of insults, including aging, excessive noise, and exposure to a variety of drugs including aminoglycoside antibiotics. Death of sensory hair cells underlies the majority of permanent hearing loss and balance disorders in humans. Aminoglycoside-induced hair cell death has been characterized as apoptotic both morphologically and molecularly ( $\mathrm{Li}$ et al., 1995; Lang and Liu, 1997; Vago et al., 1998; Forge and Li, 2000). Recently aminoglycoside-induced hair cell death has been shown to be mediated by a family of proteases called caspases (Forge and Li, 2000; Matsui et al., 2002a,b). Caspases are cysteinedependent, aspartate-specific proteases that are involved in developmental programmed cell death and apoptotic cell death in a large number of systems (for review, see Stennicke and Salvesen, 2000; Strasser et al., 2000). Like most proteases, caspases are synthesized as inactive proenzymes (zymogens) and are activated by cleavage of their prodomains. There are 14 known caspases in mammals; approximately half of them are thought to participate in the apoptotic destruction of cells. Apoptosis-related caspases have been categorized into upstream initiator caspases and downstream effector caspases (for review, see Budihardjo et al., 1999). The primary upstream initiator caspases are caspase- 8 and caspase-9. Caspase-8 is activated in response to ligation of cellsurface receptors containing a death-domain motif, including Fas and tumor necrosis factor $\alpha(\mathrm{TNF} \alpha)$ receptor (TNFR-1) (for review, see Strasser et al., 2000). Caspase-9 activation requires the release of cytochrome $c$ from mitochondria and formation of a multiprotein complex consisting of cytochrome $c$, apaf-1, dATP,

Received April 12, 2002; revised July 16, 2002; accepted July 18, 2002.

This work was supported by National Institutes of Health Grants DC-02854 and DC-00461. We thank Dr. Elizabeth Oesterle for guidance regarding cultures, Glen MacDonald for assistance with confocal imaging, and Laurie Johnson for assistance with preparation of this manuscript.

Correspondence should be addressed to Dr. Edwin W Rubel, Virginia Merrill Bloedel Hearing Research Center, Box 357923, University of Washington, Seattle, WA 98195-7293. E-mail: rubel@u.washington.edu.

Copyright (C) 2002 Society for Neuroscience $0270-6474 / 02 / 228532-09 \$ 15.00 / 0$ neomycin. The inhibition of caspase-9-like activity provided significant protection of hair cells exposed to neomycin, whereas the inhibition of caspase-8-like activity was not effective in preventing neomycin-induced hair cell death. In addition, caspase- 9 inhibition prevented the activation of downstream caspase- 3 , whereas the inhibition of caspase-8 did not. These data indicate that caspase- 9 is the primary upstream caspase mediating neomycin-induced hair cell death in this preparation.

Key words: hair cell; aminoglycoside; caspase; apoptosis; cell death; mitochondria; ototoxicity and procaspase-9 (Li et al., 1997; Zhou et al., 1999; Yuan and Yankner, 2000). Once activated these initiator caspases can cleave and activate downstream effector caspases, such as caspase-3. Effector caspases then carry out the apoptotic program by cleaving proteins necessary for cell survival, including Bcl-2, inhibitors of deoxyribonucleases, and cytoskeletal proteins (Lazebnik et al., 1994; Cheng et al., 1997; Kothakota et al., 1997; Kirsch et al., 1999).

Recent evidence that broad-spectrum inhibition of caspase activity can prevent aminoglycoside-induced hair cell apoptosis in some systems (Forge and Li, 2000; Matsui et al., 2002a,b) prompted us to evaluate which specific caspases are involved in aminoglycoside-induced hair cell death in a mature mouse inner ear sensory epithelium in whole-organ cultures. This information is critical to an understanding of the mechanisms of aminoglycoside-induced hair cell death and to the design of potential therapeutic interventions to protect hair cells.

\section{MATERIALS AND METHODS}

Animals. Three- to six-week-old CBA/CaJ mice were obtained from The Jackson Laboratory (Bar Harbor, ME) and maintained in the University of Washington Animal Care Facility. All experiments were approved by the University of Washington Institutional Animal Care and Use Committee. Animals were killed by an overdose of pentobarbital.

Utricle cultures. The utricles were dissected using sterile technique and were cultured free-floating (1-6 utricles per well) in 24-well tissue culture plates. Utricles were cultured whole without removing the otoconia. The culture medium consisted of basal medium Eagle supplemented with Earle's balanced salt solution $(2: 1 \mathrm{v} / \mathrm{v})$ and $5 \%$ fetal bovine serum (all medium components from Invitrogen, Carlsbad, CA). Neomycin sulfate (Pharma-Tek, Huntington, NY) was prepared as a $100 \mathrm{~mm}$ stock solution in sterile water and added directly to culture wells at final concentrations ranging from 0.1 to $7.0 \mathrm{~mm}$. No neomycin was added to control cultures. The utricles were incubated for $12-24 \mathrm{hr}$ at $37^{\circ} \mathrm{C}$ in a $5 \% \mathrm{CO}_{2}$ and $95 \%$ air environment (Forma Scientific, Marietta, $\mathrm{OH}$ ).

Immunohistochemistry. At the end of the culture period utricles were fixed overnight at $4^{\circ} \mathrm{C}$ in $4 \%$ paraformaldehyde in phosphate buffer. After fixation otoconia were removed by a stream of PBS applied via a syringe with a 26 gauge needle. Utricles were then incubated in blocking solution ( $2 \%$ bovine serum albumin, $0.4 \%$ normal goat serum, $0.4 \%$ 
normal horse serum, and $0.4 \%$ Triton X-100 in PBS) for $3 \mathrm{hr}$ at room temperature (RT). Endogenous peroxidases were quenched using 1\% $\mathrm{H}_{2} \mathrm{O}_{2}$ in PBS for $30 \mathrm{~min}$ at RT. For hair cell counts, utricles were double-labeled in whole mount using a monoclonal antibody against calmodulin (Sigma, St. Louis, MO) and a polyclonal antibody against calbindin (Chemicon, Temecula, CA). Utricles were incubated overnight at $4^{\circ} \mathrm{C}$ in primary antibodies diluted in blocking solution (calmodulin, 1:200; calbindin, 1:250). After washing thoroughly in PBS and $0.1 \%$ Triton X-100, the utricles were incubated for $2 \mathrm{hr}$ at RT in secondary antibodies diluted in blocking solution as follows: biotinylated horse anti-mouse IgG (1:200; Vector Laboratories, Burlingame, CA) and Alexa 594-conjugated goat anti-rabbit IgG (1:500; Molecular Probes, Eugene, OR). For labeling using peroxidase, the utricles were then washed and incubated for $2 \mathrm{hr}$ in avidin-biotin-horseradish peroxidase complex (Vector Laboratories). The tissues were rinsed in $0.05 \mathrm{~m}$ Tris buffer, $\mathrm{pH}$ 7.4 , and placed in diaminobenzidine $(0.375 \mathrm{mg} / \mathrm{ml}$ in $0.05 \mathrm{M}$ Tris $+0.1 \%$ $\mathrm{H}_{2} \mathrm{O}_{2}$ ) for 5-12 min at RT. The utricles were whole-mounted in Vectashield (Vector Laboratories) and coverslipped.

For active caspase immunohistochemistry, utricles were fixed as described above and processed using anti-active caspase- 8 (1:1000, antibody obtained through a material transfer agreement with SmithKline Beecham, King of Prussia, PA) or anti-active caspase-9 (1:100; Cell Signaling Technology, Beverly, MA). The utricles were incubated overnight in primary antibody as described above. The secondary antibody was Alexa 488-conjugated goat anti-rabbit IgG (1:200; Molecular Probes). Hair cell stereocilia were labeled using rhodamine phalloidin (1:50 in PBS; Molecular Probes).

Hair cell counts. Utricles were examined on a Leitz (Wetzlar, Germany) Aristoplan upright microscope using a $40 \times$ objective. Hair cell density was measured using a $10 \times 10$ eyepiece reticule. At the magnification used, each square of the reticule was $30 \mu \mathrm{m}$ on each side. Calbindin-positive hair cells in the striolar region were counted in each of four randomly selected $900 \mu \mathrm{m}^{2}$ areas using a Texas Red filter set. Calmodulin-positive hair cells in the extrastriolar region were counted in four randomly selected $900 \mu \mathrm{m}^{2}$ areas under Nomarski differential interference optics. The four striolar and four extrastriolar hair cell counts were each averaged to produce one striolar and one extrastriolar hair cell density for each utricle examined. At least five utricles were examined for each experimental condition.

In situ substrate detection of activated caspases. In addition to immunochemical detection, caspase activity was also examined using the fluorescent caspase substrates fam-VAD-fmk (general caspase substrate), fam-DEVD-fmk (caspase-3 substrate), fam-LEHD-fmk (caspase-9 substrate), and fam-LETD-fmk (caspase-8 substrate). All fluorescent substrates were obtained from Intergen (Purchase, NY) and used according to the manufacturer's protocols. The utricles were cultured in the presence or absence of $1 \mathrm{~mm}$ neomycin for $12 \mathrm{hr}$. The $12 \mathrm{hr}$ culture period was selected for caspase detection experiments to facilitate examination of the hair cells that were shown to be dead by $24 \mathrm{hr}$ in neomycin. Fluorescent substrate was added directly to the culture medium (final concentration, $5 \mu \mathrm{M}$ ) for the final hour in culture. After $1 \mathrm{hr}$ in substrate the utricles were washed three times for 15 min each at $37^{\circ} \mathrm{C}$ in the wash buffer supplied by the manufacturer. The utricles were then fixed overnight at $4^{\circ} \mathrm{C}$ in the fixative supplied by the manufacturer. After fixation and otoconia removal, the utricles were incubated for $2 \mathrm{hr}$ at RT in rhodamine phalloidin as above. The utricles were then rinsed with PBS, mounted, and coverslipped. Whole-mounted utricles were viewed with a confocal laser scanning microscope (MRC-1024; Bio-Rad, Hercules, CA) using LaserSharp version 2.1 software (Bio-Rad). To ensure that labeled cells were hair cells and not supporting cells, $z$-series optical sections were limited to a $z$-axis depth of $\leq 5 \mu \mathrm{m}$ from the luminal surface (apex of hair cells) and were collected to include the phalloidin-labeled stereocilia. Data were processed digitally using NIH Image and Adobe Photoshop (Adobe, Mountain View, CA).

Caspase inhibition. Caspases were inhibited using the peptide inhibitors z-VAD-fmk (general caspase inhibitor), z-IETD-fmk (inhibitor of caspase-8-like activity), and z-LEHD-fmk (inhibitor of caspase-9-like activity), all from Enzyme Systems Products (Livermore, CA). For inhibitor experiments, the utricles were cultured for $2 \mathrm{hr}$ in $25-100 \mu \mathrm{M}$ inhibitor alone before the addition of neomycin to $1 \mathrm{mM}$. Cultures were then incubated in the presence of both neomycin and caspase inhibitor for an additional $24 \mathrm{hr}$. At the end of the culture period, utricles were fixed in $4 \%$ paraformaldehyde and processed for hair cell counts as described above.

Statistical methods. Statistical analysis was performed by one-way
ANOVA using StatView version 5.0 software (SAS Institute, Cary, NC). ANOVA was performed separately for striolar and extrastriolar regions for each experiment. Individual comparisons were performed using Fisher's PLSD and Scheffé's post hoc tests. The results were considered statistically significant if $p<0.05$.

\section{RESULTS}

Figure 1 shows cultured utricles double-labeled for calmodulin and calbindin. Calmodulin (Fig. 1A,C,E) labels all hair cells of the utricle, whereas calbindin (Fig. $1 B, D, F$ ) labels type I hair cells of the striolar region. Using the culture methods described, hair cells of both the extrastriolar and striolar regions are retained in good condition after $24 \mathrm{hr}$ in vitro in the absence of neomycin (Fig. 1A,B). Table 1 shows hair cell densities for utricles that were fixed without being cultured and utricles cultured for $24 \mathrm{hr}$ in the presence or absence of $1 \mathrm{~mm}$ neomycin. These data indicate that in the absence of neomycin, $<5 \%$ of hair cells are lost during the first $24 \mathrm{hr}$ in vitro. The utricles cultured for $24 \mathrm{hr}$ in the presence of $1 \mathrm{~mm}$ neomycin $(n=10)$ show significant $(p<0.01)$ loss of hair cells in the striolar region $\left[5.35 \pm 1.65(\mathrm{SD})\right.$ hair cells $/ 900 \mu \mathrm{m}^{2}$ for neomycin-treated vs $7.91 \pm 1.59$ for control cultures] (Fig. $1 C, D$ ). At $5 \mathrm{~mm}$ neomycin, the majority of hair cells are lost after $24 \mathrm{hr}$ in vitro (Fig. 1E,F).

Figure 2 shows the dose-response relationship between neomycin concentration and hair cell density for utricles cultured for $24 \mathrm{hr}$ in the presence or absence of neomycin. Hair cell density is expressed as the percentage of surviving hair cells relative to utricles cultured for $24 \mathrm{hr}$ in the absence of neomycin. The hair cell density decreased as the neomycin dose increased for both the striolar and extrastriolar regions until virtually all hair cells were absent from the utricles cultured in $7 \mathrm{~mm}$ neomycin. For comparison, the hair cell densities are also shown for undamaged utricles that were not cultured. Hair cells of the striolar region were more sensitive to neomycin-induced death than those of the extrastriolar region. This is particularly evident at the steepest part of the dose-response function.

\section{Caspase inhibition protects against neomycin-induced hair cell death}

The general caspase inhibitor z-VAD-fmk was used to test whether caspase activity is necessary for neomycin-induced hair cell death. Utricles were cultured for $24 \mathrm{hr}$ in the presence of 1 mM neomycin with or without $100 \mu \mathrm{M} z-V A D-f m k$. Figure 3 shows hair cell densities for striolar and extrastriolar regions in fixed utricles double-labeled for calmodulin and calbindin. Culturing in the presence of $100 \mu \mathrm{M} \mathrm{z-VAD-fmk} \mathrm{resulted} \mathrm{in} \mathrm{significant} \mathrm{pro-}$ tection of hair cells exposed to neomycin versus culturing in the presence of neomycin alone $(p<0.05$ for both striolar and extrastriolar regions, one-way ANOVA). Furthermore, utricles cultured in neomycin and z-VAD-fmk had hair cell densities that were not statistically different from control values (utricles cultured without neomycin).

\section{Activation of specific caspases}

Activation of individual caspases was examined using both immunochemistry and fluorescent substrate detection in utricles cultured for $12 \mathrm{hr}$ in $1 \mathrm{~mm}$ neomycin. The substrate consists of a fluorophore bound to a four-amino acid peptide comprised of the consensus sequence for cleavage by a specific caspase. The substrate binds irreversibly to the active site of the activated caspase of interest (Bedner et al., 2000). Figure 4 shows representative examples from experiments that examined fluorescent caspase-3 substrate activation in hair cells of utricles cultured for $12 \mathrm{hr}$ in 

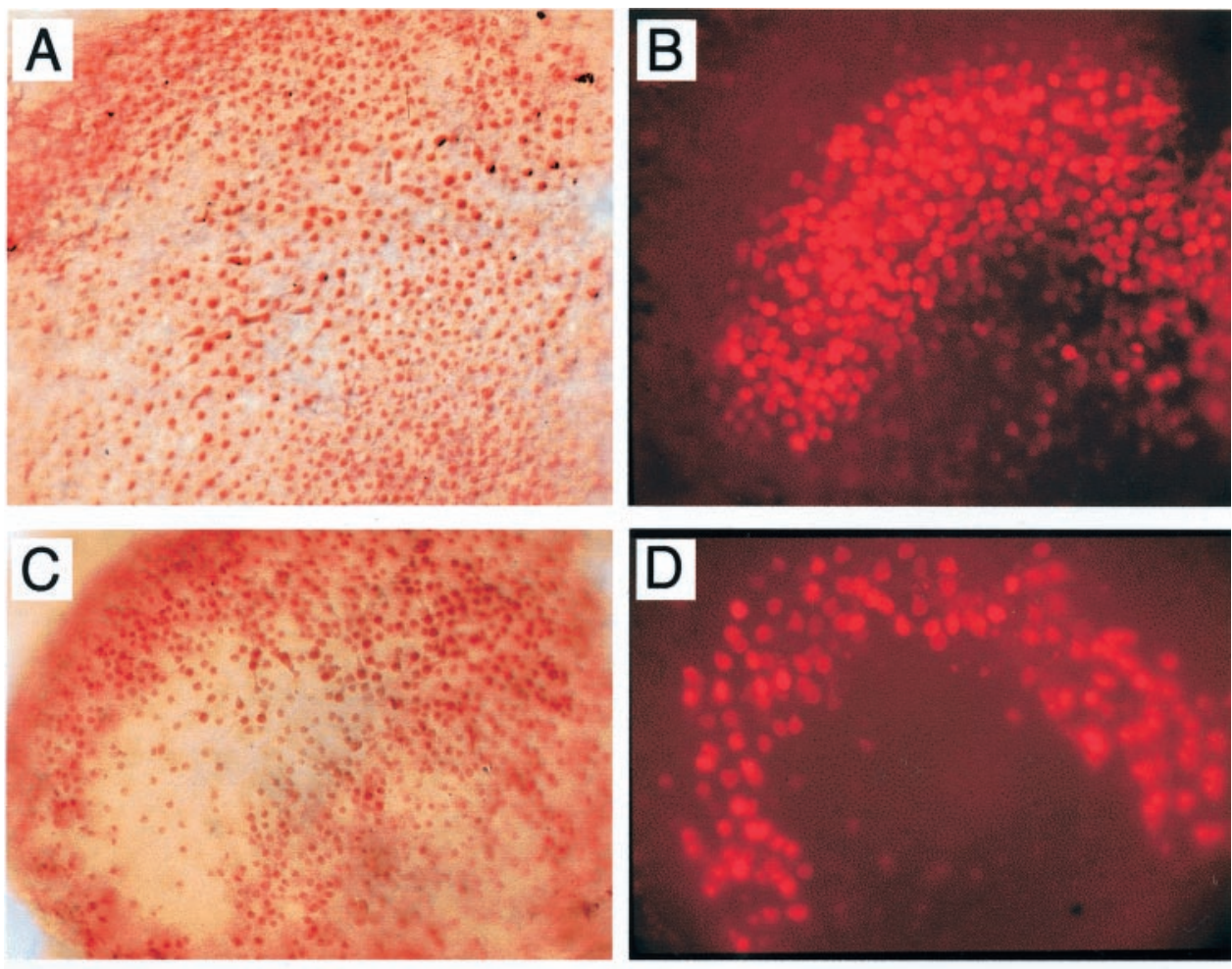

Figure 1. Cultured utricles double-labeled for calmodulin and calbindin. The utricles were cultured for $24 \mathrm{hr}$ without neomycin $(A, B)$, with $1 \mathrm{~mm}$ neomycin $(C, D)$, or with $5 \mathrm{~mm}$ neomycin $(E, F)$. After the culture period the utricles were fixed and doublelabeled using antibodies directed against calmodulin $(A, C, E)$, which labels all hair cells in the utricle, and calbindin $(B, D, F)$, which labels the type I hair cells in the striolar region. Exposure to $1 \mathrm{~mm}$ neomycin $(C, D)$ resulted in significant loss of striolar hair cells compared with control cultures. At a dose of $5 \mathrm{~mm}$ neomycin $(E, F)$ the majority of hair cells are missing in both the extrastriolar and striolar regions. Scale bar, $50 \mu \mathrm{m}$.
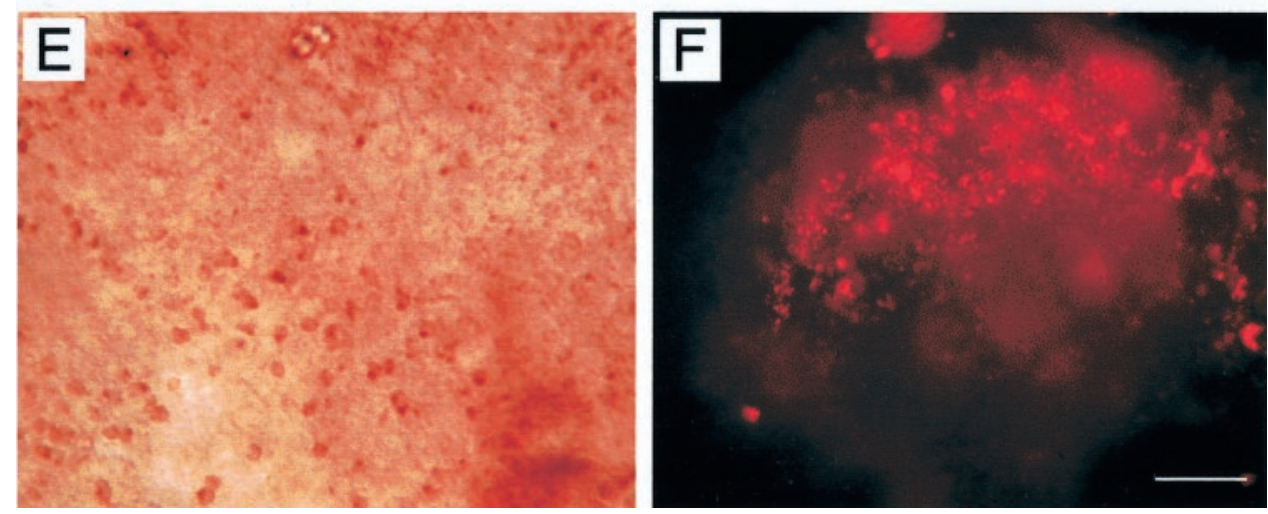

control media (Fig. $4 A)(n=10)$ or $1 \mathrm{~mm}$ neomycin (Fig. $4 B)$ $(n=10)$. Caspase- 3 is robustly activated in hair cells in response to neomycin exposure. Although some activation of caspase- 3 was evident in control cultures (Fig. $4 A$ ), its extent was consistently much less than that seen in response to neomycin exposure (Fig. $4 B$ ). The results shown in Figure 4 were exemplary of every experiment; thus, it was not necessary to quantify the difference in caspase- 3 activation between utricles cultured in the absence versus the presence of neomycin.

Figure 5 shows caspase-9 activation in control utricles (Fig. $5 A, C$ ) and utricles exposed to $1 \mathrm{~mm}$ neomycin (Fig. 5B,D). Caspase- 9 activation was assayed using two independent tech-

Table 1. Hair-cell densities are shown for both striolar and extrastriolar regions in utricles that were fixed without being cultured and utricles cultured for $\mathbf{2 4}$ hours in the absence or presence of neomycin. Hair cells were counted in each of four extrastriolar and four striolar regions (900 $\mu \mathrm{m}^{2}$ per region) in each utricle. The counts of the individual regions were averaged to give a mean extrastriolar and mean striolar hair cell density for each utricle

\begin{tabular}{|c|c|c|c|c|c|}
\hline Experimental condition & $\begin{array}{l}\text { Time in culture } \\
\text { (hours) }\end{array}$ & $n$ & Neomycin & $\begin{array}{l}\text { Extrastriolar }(E) \\
\text { or striolar }(S)\end{array}$ & $\begin{array}{l}\text { Hair cells per } 900 \mu \mathrm{M}^{2} \\
(\text { mean } \pm \mathrm{SD})\end{array}$ \\
\hline Uncultured & 0 & 5 & N/A & $\mathrm{E}$ & $15.6 \pm 0.59$ \\
\hline Uncultured & 0 & 5 & N/A & S & $8.66 \pm 1.15$ \\
\hline Cultured & 24 & 6 & 0 & $\mathrm{E}$ & $16.41 \pm 2.75$ \\
\hline Cultured & 24 & 6 & 0 & S & $7.91 \pm 1.39$ \\
\hline Cultured & 24 & 10 & $1 \mathrm{mM}$ & $\mathrm{E}$ & $12.58 \pm 2.58$ \\
\hline Cultured & 24 & 10 & $1 \mathrm{mM}$ & S & $5.35 \pm 1.65$ \\
\hline
\end{tabular}




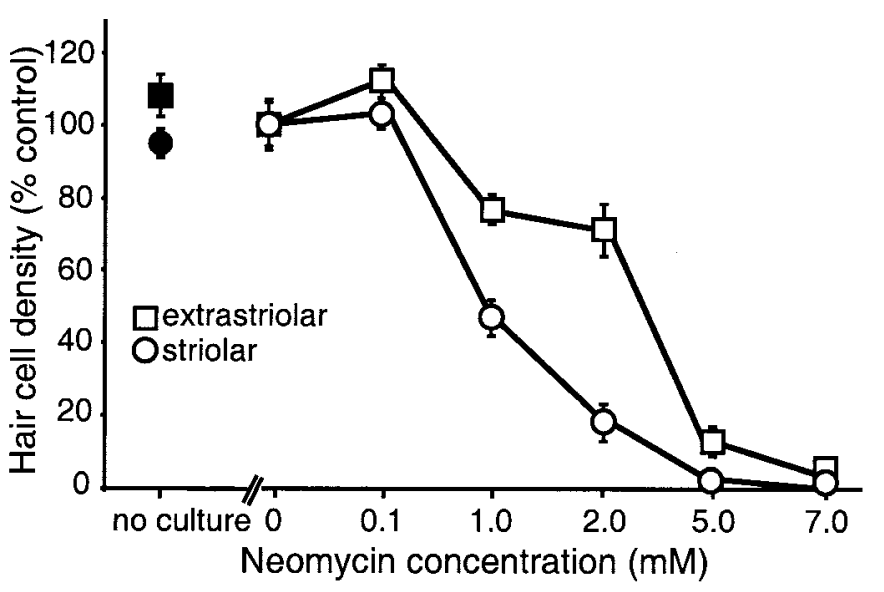

Figure 2. Relationship between neomycin concentration and hair cell density. The utricles were cultured for $24 \mathrm{hr}$ in various concentrations of neomycin and then double-labeled for calmodulin and calbindin. The hair cells in each utricle were counted and averaged from four striolar and four extrastriolar regions of $900 \mu \mathrm{m}^{2}$ each. The hair cell density is expressed as a percentage of the control value (cultured without neomycin). The hair cell density decreased systematically as the neomycin concentration increased. For comparison, the unconnected filled symbols show hair cell densities for utricles that were not cultured. Mean hair cell densities \pm SEM, $n=5-10$ utricles per group.

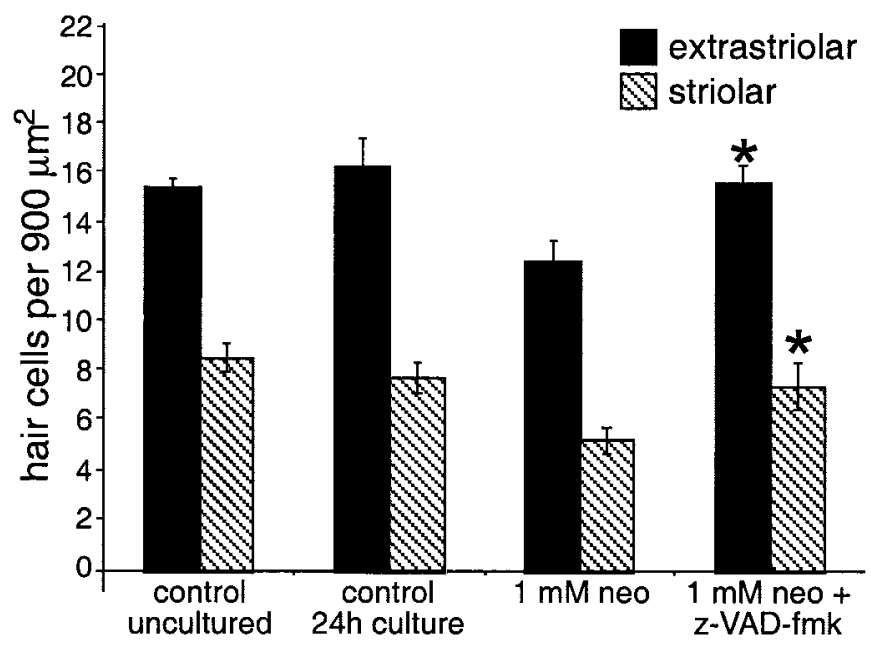

Figure 3. Protection of hair cells by broad-spectrum caspase inhibition. The utricles were cultured for $24 \mathrm{hr}$ in control media $(n=5), 1 \mathrm{~mm}$ neomycin $(n=8)$, or $1 \mathrm{~mm}$ neomycin plus $100 \mu \mathrm{M} \mathrm{z}$-VAD-fmk $(n=5)$, a broad-spectrum caspase inhibitor. The utricles were double-labeled for calmodulin and calbindin, and the hair cells were counted. z-VAD-fmk provided significant protection of hair cells in both the striolar and extrastriolar regions compared with utricles cultured in neomycin alone $\left({ }^{*} p<0.05\right.$, one-way ANOVA). Error bars indicate \pm SEM.

niques. Fluorescent caspase- 9 substrate detection $(n=7$ controls, 7 treated) is shown in Figure 5, $A$ and $B$. Immunohistochemistry using an antibody specific for the activated form of caspase-9 $(n=$ 8 controls, 10 treated) is shown in Figure 5, $C$ and $D$. Very little caspase- 9 activation is seen by either method in utricles cultured for $12 \mathrm{hr}$ in the absence of neomycin (Fig. 5A,C). However, there is marked caspase- 9 activation in utricles cultured in $1 \mathrm{~mm}$ neomycin (Fig. 5B,D). Phalloidin labeling of F-actin was used to visualize hair cell stereocilia. The visualization of the stereocilia was then used to limit the $z$-axis depth of field to $5 \mu \mathrm{m}$. Therefore, these data indicate that caspase- 9 is activated in hair cells. No caspase-9 substrate activation was seen in the support cell layer. Again, the difference in caspase- 9 activation between control and neomycin-exposed hair cells was so clear and consistent that it was not necessary to quantify these results.

Similar experiments were performed to assess caspase- 8 activation in the hair cells of mouse utricles cultured for $12 \mathrm{hr}$ in the presence and absence of $1 \mathrm{~mm}$ neomycin (Fig. 6). Figure 6, $A$ and $B$, shows examples from experiments examining caspase- 8 fluorescent substrate detection ( $n=7$ controls, 7 treated). Figure $6, C$ and $D$, shows examples of immunohistochemistry using an antibody specific for activated caspase- 8 ( $n=10$ controls, 10 treated). Activated caspase- 8 is observed in hair cells in both control (Fig. $6 A, C$ ) and neomycin-treated (Fig. $6 B, D$ ) utricles. However, quantification of the number of hair cells showing activated caspase- 8 by substrate detection (Fig. 7) indicates that hair cells with activated caspase- 8 were two to three times more abundant in the utricles exposed to neomycin than in the control utricles $(p<$ $0.01 ; n=7$ utricles per condition). As with caspase-9, caspase-8 activation was not observed in the support cell layer.

\section{Inhibition of specific caspases}

Substrate detection and immunochemistry data indicate that caspase-9 is robustly activated in hair cells exposed to neomycin for $12 \mathrm{hr}$ (Fig. 5). To determine whether caspase-9-like activity is necessary for neomycin-induced hair cell death, utricles were cultured for $24 \mathrm{hr}$ in the presence of neomycin and z-LEHD-fmk, an irreversible peptide inhibitor that is relatively specific for caspase-9 (Thornberry et al., 1997). The results are shown in Figure $8 A$. The experimental conditions consisted of cultured control utricles, utricles cultured in $1 \mathrm{~mm}$ neomycin, and utricles cultured in the presence of both $1 \mathrm{~mm}$ neomycin and varying concentrations of caspase-9 inhibitor. Inhibition of caspase-9 (100 $\mu \mathrm{m}$ z-LEHD-fmk) was sufficient to provide significant protection of neomycin-exposed hair cells in both striolar and extrastriolar regions ( $p<0.01$ for both regions, one-way ANOVA, $n=7$ utricles). This protection remained significant for the striolar region at $50 \mu \mathrm{m} z$-LEHD-fmk $(p<0.05)$ and was lost for both areas at $25 \mu \mathrm{m}$ z-LEHD-fmk.

In contrast to caspase-9 inhibition, inhibition of caspase-8-like activity did not protect hair cells against neomycin-induced death. Figure $8 B$ shows the results of experiments using z-IETDfmk, an irreversible peptide inhibitor that is relatively specific for caspase-8. There was no significant increase in hair cell survival in utricles cultured in neomycin plus $100 \mu \mathrm{M}$ z-IETD-fmk compared with those cultured in neomycin alone.

\section{Inhibition of caspase-9 prevents activation of caspase-3}

In view of the results presented above, an experiment was designed to determine which of the upstream caspases (caspase- 8 or caspase-9 or both) cleaves and activates downstream caspase-3. Utricles were incubated in $1 \mathrm{~mm}$ neomycin in the absence of caspase inhibitor or in the presence of either the inhibitor of caspase-8-like activity (z-IETD-fmk) or the inhibitor of caspase9-like activity (z-LEHD-fmk). The substrate activation assay was then performed using the fluorescent caspase- 3 substrate. The qualitative results of this experiment are shown in Figure 9. In the absence of neomycin, there is very little activation of caspase-3 (Fig. 9A). In the presence of neomycin and no inhibitor, there is robust activation of caspase-3 (Fig. 9B). Treatment with neomycin and $100 \mu \mathrm{M}$ z-IETD-fmk (caspase-8 inhibitor) results in significant activation of caspase-3 (Fig. 9C). However, in the presence 
Figure 4. Caspase-3 substrate activation. The utricles were cultured for $12 \mathrm{hr}$ in control media $(A)$ or $1 \mathrm{~mm}$ neomycin $(B)$. The green fluorescent caspase-3 substrate fam-DEVDfmk was added for the final hour in culture. After the culture period the utricles were fixed and stereocilia were labeled using rhodamine phalloidin. Shown are brightest point projections of $z$-series confocal micrographs that were limited to a depth of $5 \mu \mathrm{m}$ in the $z$-axis. $A$, Very little or no activation of caspase- 3 is seen in control utricles. $B$, Robust caspase- 3 activation is seen in utricles cultured in the presence of neomycin. Scale bar, $20 \mu \mathrm{m}$.
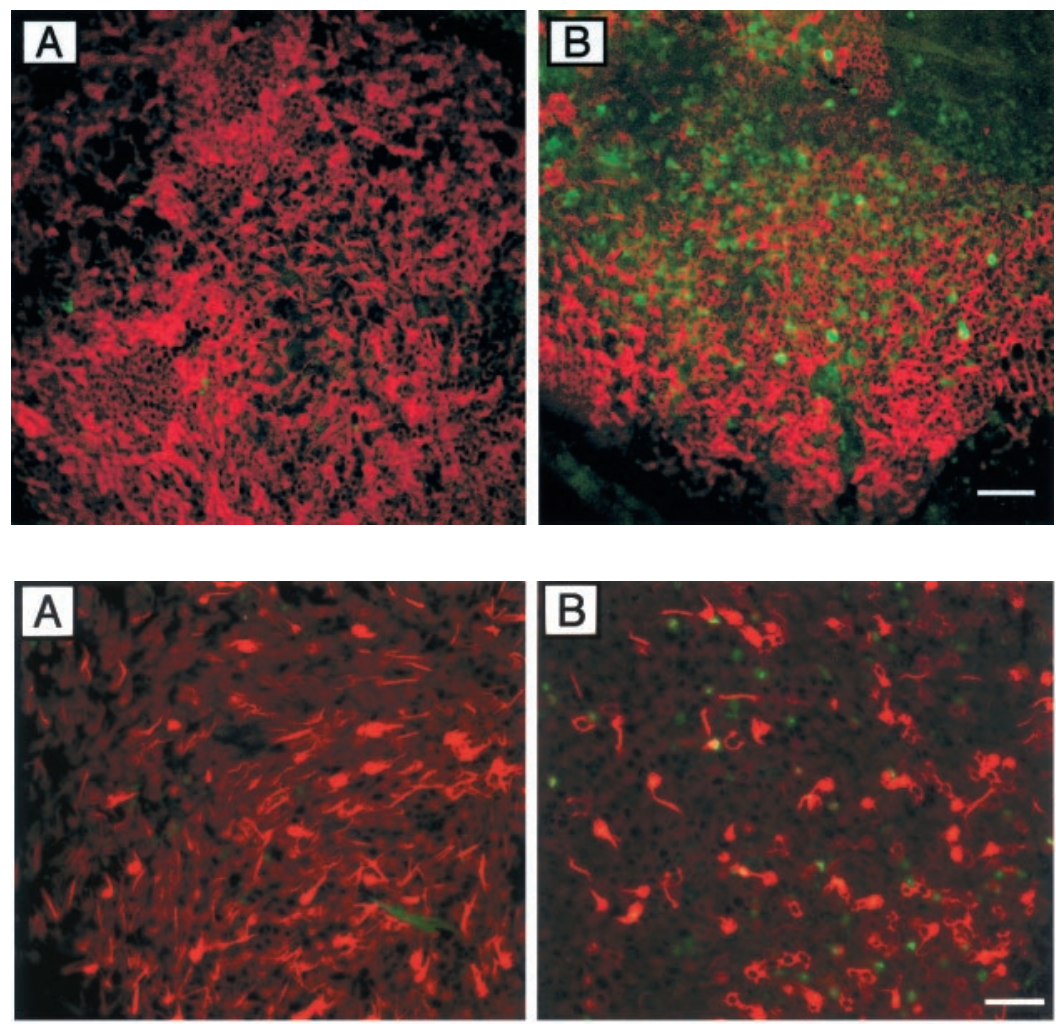

Figure 5. Caspase-9 activation. The utricles were cultured for $12 \mathrm{hr}$ in control media $(A, C)$ or $1 \mathrm{~mm}$ neomycin $(B, D)$. Caspase-9 activation (green) was detected using the fluorescent caspase-9 substrate fam-LEHD-fmk $(A, B)$ and immunohistochemistry $(C, D)$. Stereocilia were labeled using rhodamine phalloidin. Shown are brightest point projections of $z$-series confocal micrographs that were limited to a depth of $5 \mu \mathrm{m}$ in the $z$-axis. $A$, Little activation of caspase-9 is seen in control utricles using the substrate detection assay. $B$, Robust caspase-9 activation is seen in utricles cultured in the presence of neomycin. $C, D$, Immunochemistry for active caspase-9 shows very little activation in control utricles $(C)$ and marked activation (arrows) in utricles cultured in neomycin $(D)$. Scale bars: $A, B, 10 \mu \mathrm{m} ; C, D, 5 \mu \mathrm{m}$.
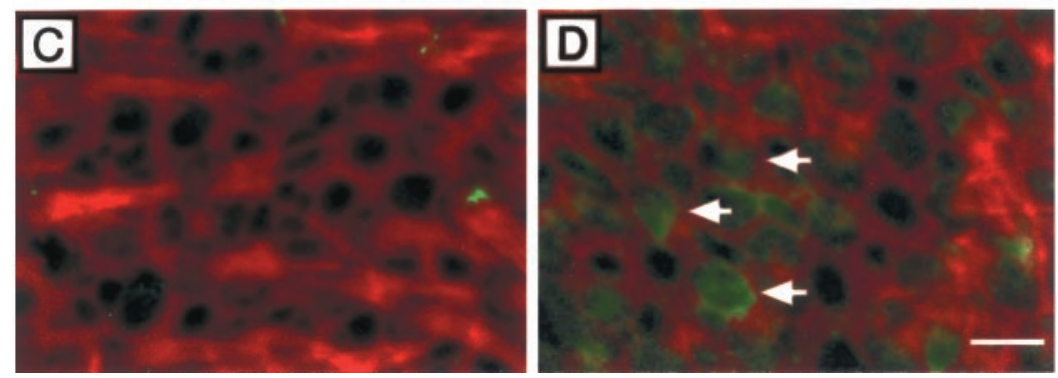

of neomycin and $100 \mu \mathrm{M}$ z-LEHD-fmk (caspase-9 inhibitor), activation of caspase-3 is substantially reduced (Fig. 9D). The data from this experiment are quantified in Figure 10. Relative to utricles cultured in neomycin alone (no inhibitor, $n=5$ ), inhibition of caspase- $8(n=5)$ resulted in no significant decrease in the number of caspase-3-positive hair cells. However, inhibition of caspase-9 resulted in a significant decrease in caspase-3-positive hair cells ( $p<0.01$; ANOVA; $n=7)$. These data suggest that caspase- 3 is activated by caspase- 9 but not by caspase- 8 .

\section{DISCUSSION}

We have demonstrated that neomycin-induced hair cell death in the adult mouse utricle in vitro is mediated by the activation of caspases. Our data indicate that both upstream caspase- 8 and upstream caspase-9, as well as downstream caspase-3, are activated in hair cells exposed to neomycin. Our data on mature mouse utricles are consistent with previous reports indicating that the general inhibition of caspase activity is sufficient to suppress aminoglycoside-induced hair cell death in gerbil, guinea pig, and chick utricles (Forge and Li, 2000; Matsui et al., 2002b). In addition, our results are consistent with data indicating that both caspase- 8 and caspase-9 (as well as caspase-3) are activated in spinal cord neurons undergoing apoptosis (Matsushita et al., 2000).

\section{Neomycin-induced hair cell death in vitro}

Comparison of hair cell densities between utricles fixed without being cultured and those cultured for $24 \mathrm{hr}$ in the absence of neomycin showed that very few hair cells were lost in the control cultures during this period. Examination of the relationship between neomycin concentration and hair cell density showed that hair cell numbers decreased as the neomycin dose increased for both the striolar and extrastriolar regions. Subsequent experiments used a concentration of $1 \mathrm{~mm}$ neomycin, a concentration that provides a significant lesion while leaving sufficient numbers of intact hair cells to examine for caspase activity.

\section{Broad-spectrum caspase inhibition protects against neomycin-induced hair cell death}

The general caspase inhibitor z-VAD-fmk is a peptide substrate that binds irreversibly to the active site of each of the known caspases (Bedner et al., 2000). The utricles cultured in the presence of neomycin and z-VAD-fmk showed significant protection of hair cells compared with the utricles cultured in neomycin alone. In fact, hair cell densities in the utricles treated with neomycin in the presence of z-VAD-fmk were within $5 \%$ of the hair cell densities of the control utricles. These data indicate that caspase activation is necessary for the hair cell death seen during the first $24 \mathrm{hr}$ in culture with neomycin. Our data do not address 

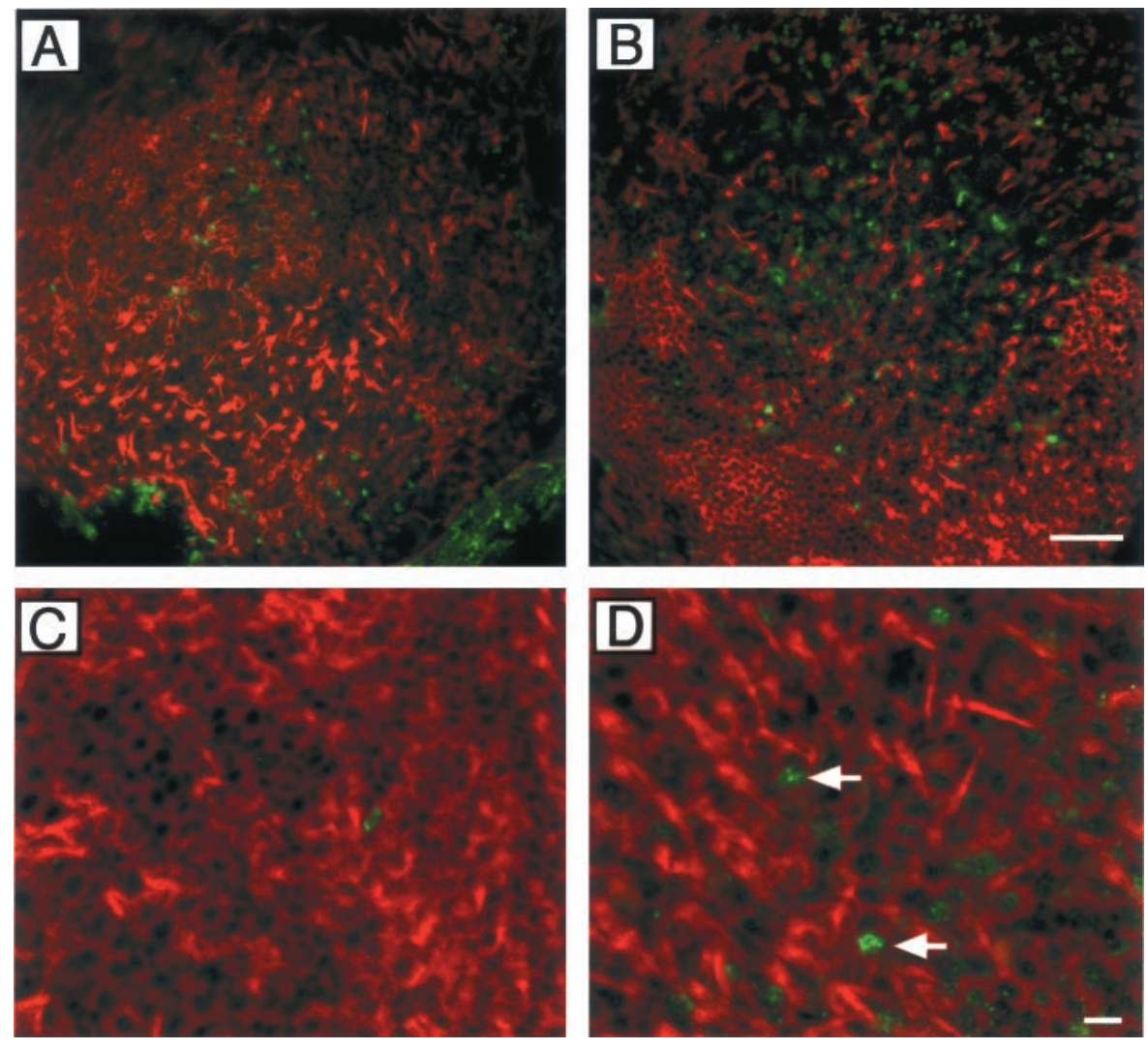

Figure 6. Caspase-8 activation. The utricles were cultured for $12 \mathrm{hr}$ in control media $(A, C)$ or $1 \mathrm{~mm}$ neomycin $(B, D)$. After the culture period the utricles were fixed, and stereocilia were labeled using rhodamine phalloidin. Shown are brightest point projections of $z$-series confocal micrographs that were limited to a depth of $5 \mu \mathrm{m}$ in the $z$-axis. $A, B$, The green fluorescent caspase- 8 substrate fam-LETD-fmk was added for the final hour in culture. Limited activation of caspase- 8 is seen in the hair cells of control utricles $(A)$. Caspase- 8 activation is increased in the utricles cultured in the presence of neomycin $(B)$. $C, D$, Immunochemistry using an antibody specific for the activated form of caspase-8. Very little active caspase- 8 immunoreactivity is detectable in control utricles $(C)$. Active caspase-8 immunoreactivity (arrows) is present in the hair cells of utricles cultured in neomycin $(D)$. Scale bars: $A, B, 20 \mu \mathrm{m}$; $C, D, 5 \mu \mathrm{m}$.

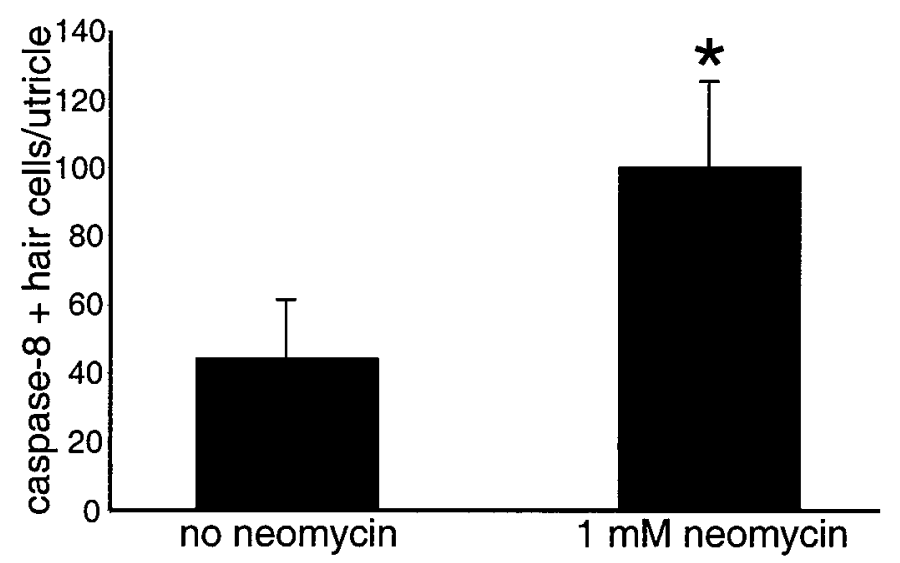

Figure 7. Quantification of active caspase- 8 substrate detection data. Hair cells showing caspase- 8 activation by the substrate detection method were counted in utricles cultured with and without $1 \mathrm{~mm}$ neomycin. Significantly more hair cells contained activated caspase- 8 in utricles cultured in neomycin compared with control utricles ( ${ }^{*} p<0.01 ; n=5$ utricles per condition). Error bars indicate means \pm SD.

whether caspase inhibition is sufficient to protect hair cells for longer periods of time. In cultured embryonic rat cortical neurons exposed to camptothecin, inhibition of caspase activity delayed apoptotic cell death for 12-24 hr, after which the cells underwent a nonapoptotic death (Stefanis et al., 1999). However, there is evidence that caspase inhibition can protect hair cells for longer periods. Forge and Li (2000) found that caspase inhibition protected hair cells in cultured gerbil and guinea pig utricles for at least $48 \mathrm{hr}$ after exposure to gentamicin. Matsui et al. (2002a) found that continuous in vivo infusion of $\mathrm{z}-\mathrm{VAD}-\mathrm{fmk}$ protected hair cells of the chicken utricle for at least $5 \mathrm{~d}$ after exposure to streptomycin.

\section{Activation of specific caspases}

The activation of specific caspases was examined using fluorescent substrate detection assays and immunohistochemistry in utricles cultured for $12 \mathrm{hr}$ in the presence or absence of $1 \mathrm{~mm}$ neomycin. For both caspase- 8 and caspase- 9 the substrate detection assay and the immunochemical data were in agreement. However, the substrate detection assay consistently showed more hair cells with activated caspase than did the immunochemical technique. These data suggest that the substrate detection assay may be more sensitive but somewhat less specific than the immunochemical technique. Both methods indicate that there is very little activation of either caspase- 3 or caspase- 9 in the control cultures, but there is robust activation of both caspase- 3 and caspase-9 in hair cells exposed to neomycin. Unlike caspase-3 and caspase-9, there appears to be activation of caspase- 8 in control cultures; this activation is moderately increased in utricles exposed to neomycin for $12 \mathrm{hr}$. Because the hair cells in these utricles were localized using rhodamine phalloidin, which does not distinguish between striolar and extrastriolar hair cells, our data do not address whether there is differential distribution of hair cells with activated caspases between the two regions. However, there was no obvious difference in substrate labeling between central versus peripheral regions in any utricle examined.

The mechanism of caspase- 8 activation in control cultures is unknown. Caspase- 8 is activated by the ligation of cell-surface receptors containing a "death effector domain" motif (Muzio et al., 1998; Budihardjo et al., 1999). Such receptors include the Fas receptor and TNFR-1. Unlike other procaspase molecules, the caspase- 8 zymogen possesses an intrinsic enzymatic activity that is $\sim 1 \%$ of the activity of the activated caspase (Muzio et al., 

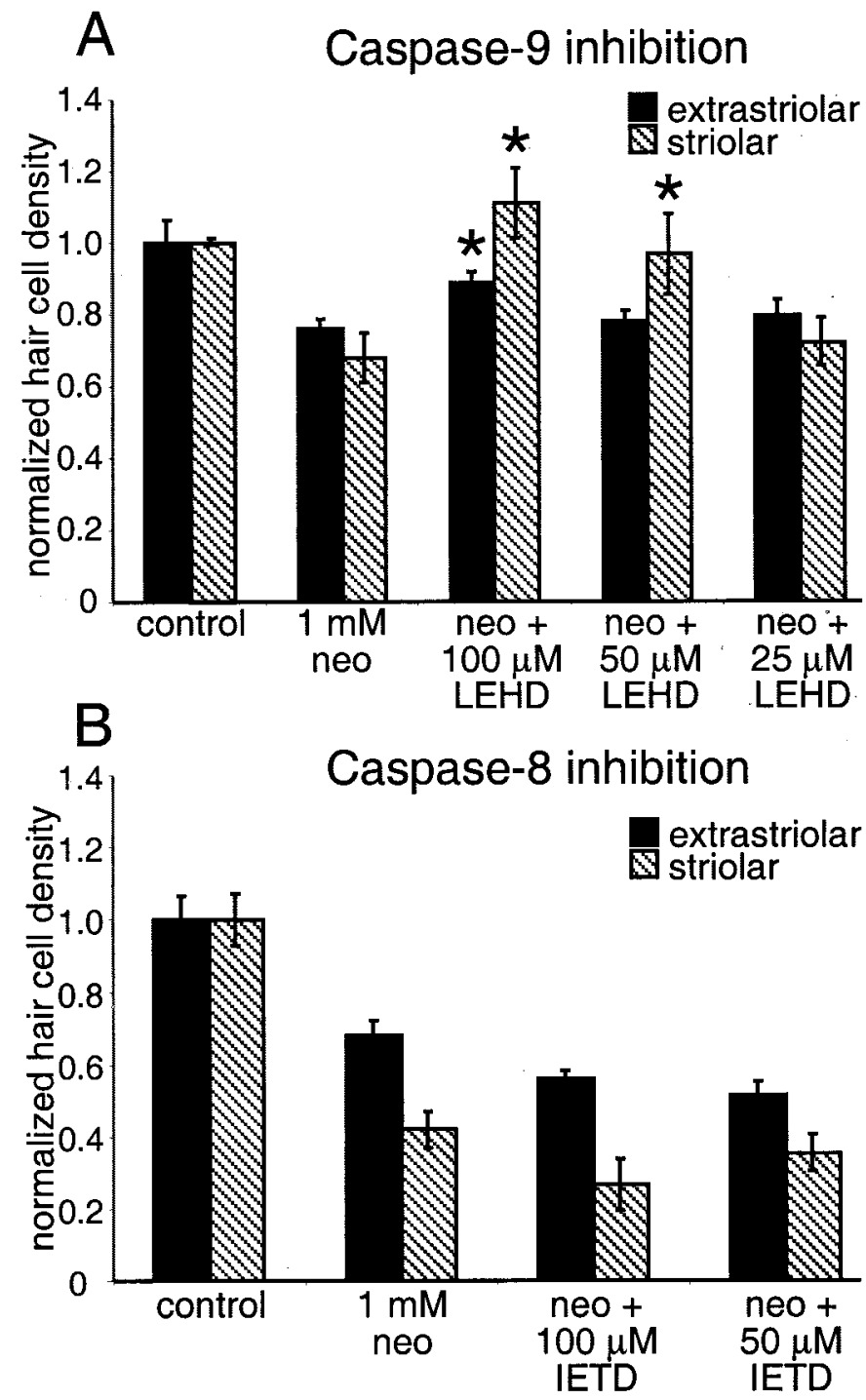

Figure 8. Inhibition of caspase-9 and caspase-8. The utricles were cultured for $24 \mathrm{hr}$ in control media, neomycin alone, or neomycin plus a peptide inhibitor of either caspase-9-like or caspase-8-like activity. $A$, The utricles were cultured in control media $(n=6), 1 \mathrm{~mm}$ neomycin $(n=8)$, or $1 \mathrm{~mm}$ neomycin plus z-LEHD-fmk, a peptide inhibitor of caspase-9, at concentrations of $100 \mu \mathrm{M}(n=7), 50 \mu \mathrm{M}(n=4)$, or $25 \mu \mathrm{M}(n=5)$. Hair cell densities were calculated for the striolar and extrastriolar regions. 100 $\mu \mathrm{M} z$-LEHD-fmk provided significant protection of hair cells in both the striolar and extrastriolar regions $\left({ }^{*} p<0.05\right.$ for the extrastriolar region, ${ }^{*} p<0.001$ for the striolar region, ANOVA). Hair cells of the striolar region (but not the extrastriolar region) were significantly protected by 50 $\mu \mathrm{M}$ z-LEHD-fmk compared with control utricles $(* p<0.05$ for the striolar region, ANOVA). No significant protection of hair cells was seen at $25 \mu \mathrm{M} \mathrm{z}$-LEHD-fmk. $B$, The utricles were cultured in control media $(n=6), 1 \mathrm{~mm}$ neomycin $(n=6)$, or $1 \mathrm{~mm}$ neomycin plus z-IETD-fmk, a peptide inhibitor of caspase-8-like activity, at either $100 \mu \mathrm{M}(n=5)$ or 50 $\mu \mathrm{M}(n=5)$ inhibitor. Caspase-8 inhibition did not result in significant protection of hair cells of either the striolar or extrastriolar region. Note: Although it appears that the means of the $1 \mathrm{~mm}$ condition differ between $A$ and $B$, they are within the normal variability and were not statistically different from one another $(p>0.05$ for both extrastriolar and striolar regions). Error bars indicate means \pm SEM.

1998). Therefore, the simplest explanation for our finding of low-level caspase- 8 activation in control cultures may be that the intrinsic enzymatic activity of procaspase- 8 was sufficient in some cells to allow substrate binding and caspase- 8 activity detection.
Caspase-8-like activity increased significantly compared with control levels in utricles exposed to neomycin. The death domain receptor responsible for activating caspase- 8 in hair cells is not known. However, cells of the chick utricle are responsive to TNF $\alpha$ in vitro (Warchol, 1999), and there are significant numbers of leukocytes present in hair cell sensory epithelia that are capable of releasing numerous cytokines (including $\mathrm{TNF} \alpha$ ) in response to injury (Bhave et al., 1998). Thus, caspase- 8 activation in response to neomycin exposure could potentially be mediated by TNFR-1. Regardless of the mechanism of caspase- 8 activation in utricular hair cells exposed to neomycin, it appears that caspase- 8 is not the primary caspase mediating hair cell death in this system because inhibition of caspase-8-like activity was not sufficient to prevent either neomycin-induced hair cell apoptosis or caspase-3 activation.

\section{Caspase-9}

Inhibition of caspase-9-like activity was sufficient to prevent both neomycin-induced hair cell death and activation of caspase-3. In fact, $100 \mu \mathrm{M}$ z-LEHD-fmk provided protection of hair cells that was comparable to the protection obtained by inhibiting all caspase activity with $z-V A D-f m k$. These data call for examination of the specificities of the peptide inhibitors. The peptide sequences of the inhibitors are based on a combinatorial examination of the amino acid sequence most efficiently cleaved by each caspase (Thornberry et al., 1997). The inhibitory constants of the caspase- 8 peptide inhibitor are $\mathrm{K}_{\mathrm{i}}=1.05 \mathrm{~nm}$ for caspase- 8 and $\mathrm{K}_{\mathrm{i}}=108 \mathrm{~nm}$ for caspase-9 (Garcia-Calvo et al., 1998). The inhibitory constants of the caspase- 9 peptide inhibitor are not known, although the preferred substrate sequence information suggests that the caspases most likely cross-inhibited by the caspase-9 inhibitor are the group I caspases (caspase-1, caspase-4, and caspase-5) (Thornberry et al., 1997; Garcia-Calvo et al., 1998). These caspases are generally thought to be involved in cytokine activation rather than apoptosis (Salvesen and Dixit, 1997). It is less likely that the caspase-9 inhibitor sequence would be an effective inhibitor of either caspase-3 or caspase-8 (GarciaCalvo et al., 1998).

Caspase- 8 activation can promote apoptosis via a caspase-9dependent mechanism. Proapototic Bid is a cytosolic protein that is cleaved by activated caspase- 8 and is then translocated to the mitochondria, where it promotes cytochrome $c$ release ( $\mathrm{Li}$ et al., 1998; Luo et al., 1998; Chou et al., 1999). Therefore, Bid can serve as a mechanism of cross-talk between these two upstream initiator caspases. However, our data indicate that both activation of caspase-3 and hair cell apoptosis occur in the presence of an inhibitor of caspase- 8 . Therefore, although neomycin-induced activation of caspase- 8 may serve to amplify the apoptotic cascade, it is not necessary for either caspase-3 activation or hair cell apoptosis.

The data showing that inhibition of caspase-9-like activity prevents activation of caspase- 3 indicates that caspase- 9 activation is upstream of caspase- 3 activation. Caspase- 9 activation requires a signal from mitochondria in the form of release of mitochondrial cytochrome $c$ into the cytoplasm (Li et al., 1997; for review, see Bossy-Wetzel and Green, 1999). Cytochrome $c$ is translocated from the mitochondria to the cytoplasm in hair cells of the chick basilar papilla after exposure to gentamicin in vitro (Cheng et al., 2002). The finding that the most pivotal caspase mediating neomycin-induced hair cell death is also the one most closely associated with mitochondrial signaling is in agreement with several lines of evidence indicating that mitochondria are a 

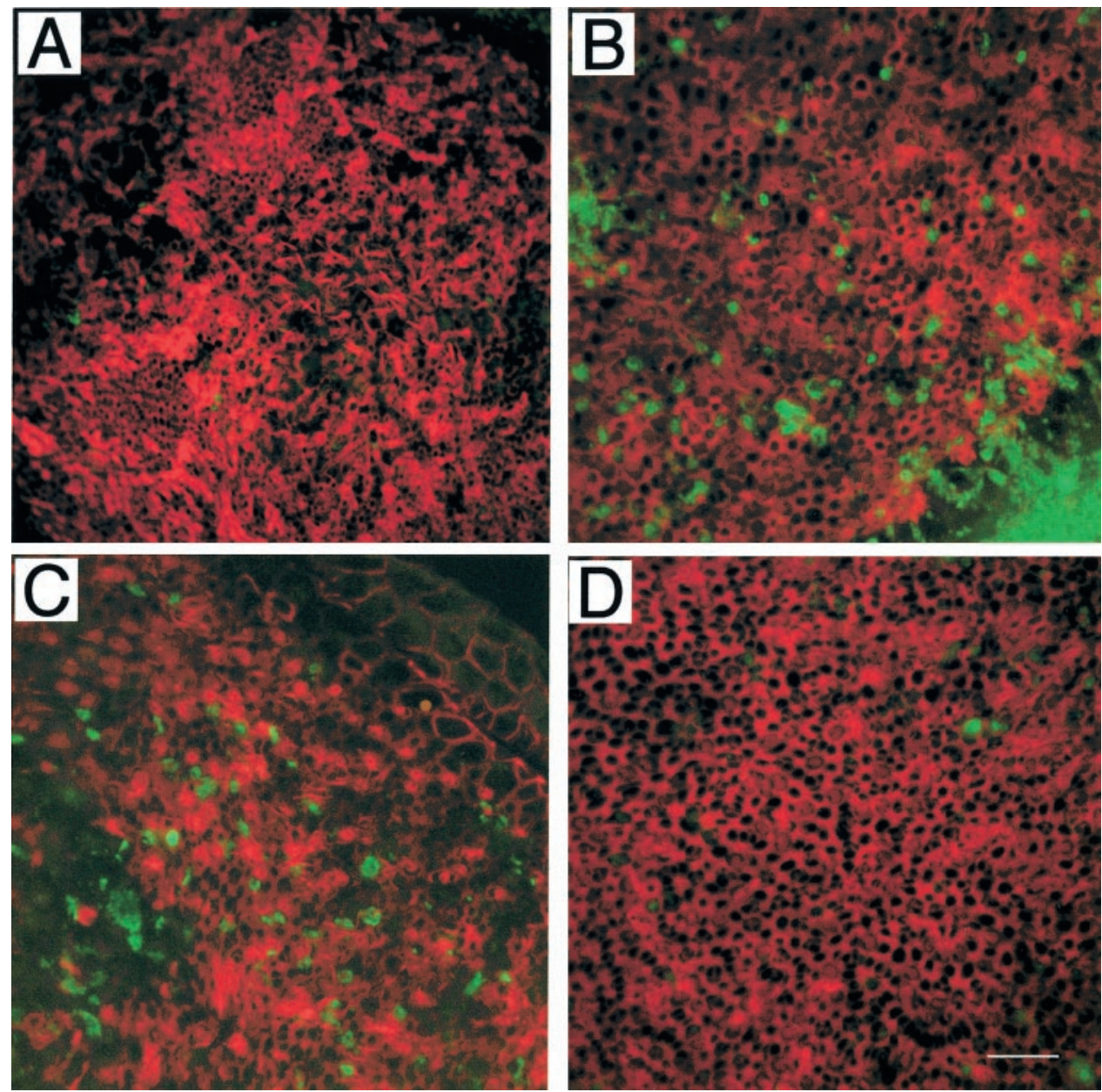

Figure 9. Inhibition of caspase-8 or caspase-9 with substrate detection of activated caspase- 3 . The utricles were cultured for $12 \mathrm{hr}$ in control media $(A)$, in $1 \mathrm{~mm}$ neomycin alone $(B)$, in $1 \mathrm{~mm}$ neomycin plus the caspase- 8 inhibitor z-IETD-fmk (100 $\mu \mathrm{M})(C)$, or in $1 \mathrm{~mm}$ neomycin plus the caspase-9 inhibitor z-LEHD-fmk $(100 \mu \mathrm{M})$ $(D)$. In all panels the green fluorescent caspase-3 substrate fam-DEVD-fmk was used to examine caspase-3 activation. Hair cell stereocilia were labeled using rhodamine phalloidin. Shown are the brightest point projections of $z$-series confocal micrographs that were limited to a depth of $5 \mu \mathrm{m}$ in the $z$-axis. $A$, In the absence of neomycin there is very little activation of caspase- 3 in hair cells. $B$, In the presence of neomycin alone there is robust activation of caspase-3 in hair cells. $C$, In the presence of neomycin and z-IETD-fmk (caspase-8 inhibitor), there is robust activation of caspase-3 in hair cells. $D$, In the presence of neomycin and z-LEHD-fmk (caspase-9 inhibitor) there is very little activation of caspase- 3 in hair cells. Scale bar, $20 \mu \mathrm{m}$. primary site of aminoglycoside damage to hair cells. First, electron microscopy studies have shown ultrastructural changes in hair cell mitochondria after aminoglycoside exposure (BaggerSjoback and Wersall, 1978; De Groot et al., 1991; Hirose et al., 1999). Secondly, reactive oxygen species (ROS) are produced in hair cells in response to aminoglycoside exposure (Clerici et al., 1996; Hirose et al., 1997, 1999; Sha and Schacht, 1999; Takumida and Anniko, 2001), and free radical scavengers can protect hair cells against aminoglycoside-induced death (Garetz et al., 1994; Song and Schacht, 1996; Sinswat et al., 2000; Sha et al., 2001). These data strongly suggest that ROS are important mediators of aminoglycoside-induced hair cell death. Mitochondria are both a target and a source of ROS. In situ-generated ROS can cause cytochrome $c$ release in primary cultures of cerebellar granule neurons (Atlante et al., 2000). Cytochrome $c$ release results in the blockade of the electron transport chain at complex III, thus increasing ROS production. Cytochrome $c$ release is required for the activation of caspase-9, which our data show is necessary for both cleavage of caspase- 3 and apoptosis in hair cells exposed to neomycin.

In summary, we have shown that neomycin-induced hair cell death in the adult mouse utricle in vitro is mediated by caspase activation. This hair cell apoptosis is mediated by activation of caspase-9, which then cleaves and activates the downstream effector caspase-3. This delineation of the specific caspase cascade in hair cells furthers our understanding of both the biology of hair cell death and potential targets for therapeutic intervention.

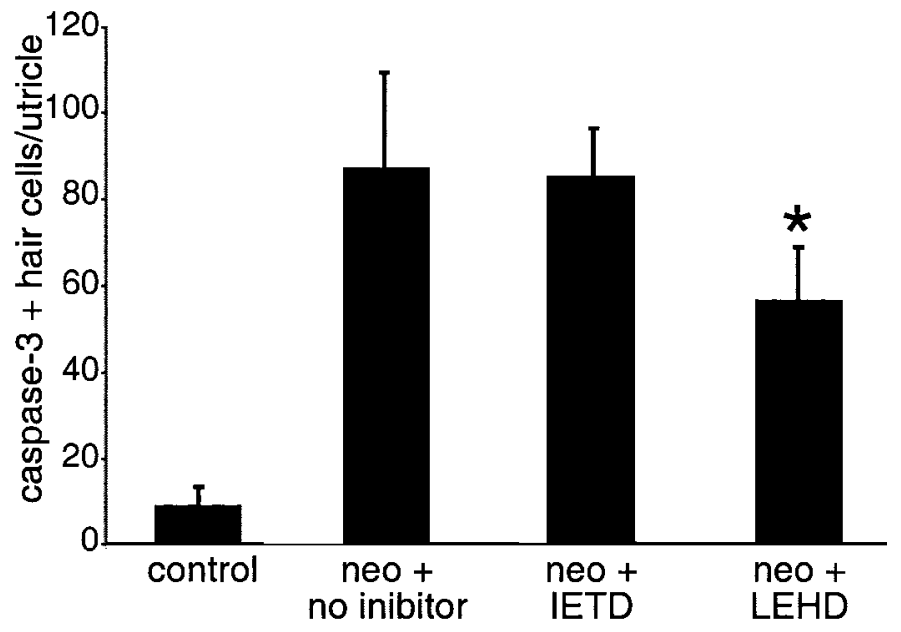

Figure 10. Quantification of caspase-3-positive hair cells in utricles cultured in the presence of inhibitors of caspase- 8 or caspase- 9 . The utricles were cultured as described in Figure 9. Caspase-3-positive hair cells were counted for utricles cultured in control media, neomycin alone, or neomycin plus peptide inhibitors of either caspase-8-like activity (z-IETDfmk) or caspase-9-like activity (z-LEHD-fmk). The inhibition of caspase-9 resulted in a significant reduction in the number of active caspase-3-positive hair cells compared with utricles cultured in neomycin alone ( $* p<0.01$; ANOVA; $n=7$ utricles). Inhibition of caspase- 8 did not result in any significant change in the number of caspase-3-positive hair cells compared with incubation in neomycin alone $(p=0.7$; ANOVA; $n=5$ utricles). Error bars indicate means \pm SD. 


\section{REFERENCES}

Atlante A, Calissano P, Bobba A, Azzariti A, Marra E, Passarella S (2000) Cytochrome $c$ is released from mitochondria in a reactive oxygen species (ROS)-dependent fashion and can operate as a ROS scavenger and as a respiratory substrate in cerebellar neurons undergoing excitotoxic death. J Biol Chem 275:37159-37166.

Bagger-Sjoback D, Wersall J (1978) Gentamicin-induced mitochondrial damage in inner ear sensory cells of the lizard Calotes versicolor. Acta Otolaryngol 86:35-51

Bedner E, Smolewski P, Amstad P, Darzynkiewicz Z (2000) Activation of caspases measured in situ by binding of fluorochrome-labeled inhibitors of caspases (FLICA): correlation with DNA fragmentation. Exp Cell Res 259:308-313.

Bhave SA, Oesterle EC, Coltrera MD (1998) Macrophage and microglialike cells in the avian inner ear. J Comp Neurol 398:241-256.

Bossy-Wetzel E, Green DR (1999) Apoptosis: checkpoint at the mitochondrial frontier. Mutat Res 434:243-251.

Budihardjo I, Oliver H, Lutter M, Luo X, Wang X (1999) Biochemical pathways of caspase activation during apoptosis. Annu Rev Cell Dev Biol 15:269-290.

Cheng EH, Kirsch DG, Clem RJ, Ravi R, Kastan MB, Bedi A, Ueno K, Hardwick JM (1997) Conversion of Bcl-2 to a Bax-like death effector by caspases. Science 278:1966-1968.

Cheng AG, Cunningham LL, Rubel EW (2002) Translocation of Cytochrome $\mathrm{c}$ in hair cells of gentamicin-treated avian basilar papilla. Abstracts of the Twenty-Fifth Annual Midwinter Research Meeting of the Association for Research in Otolaryngology. 25:134.

Chou JJ, Li H, Salvesen GS, Yuan J, Wagner G (1999) Solution structure of BID, an intracellular amplifier of apoptotic signaling. Cell 96:615-624.

Clerici WJ, Hensley K, DiMartino DL, Butterfield DA (1996) Direct detection of ototoxicant-induced reactive oxygen species generation in cochlear explants. Hear Res 98:116-124.

De Groot JCMJ, Huizing EH, Veldman JE (1991) Early ultrastructural effects of gentamicin cochleotoxicity. Acta Otolaryngol (Stockh) $111: 273-280$

Forge A, Li L (2000) Apoptotic death of hair cells in mammalian vestibular sensory epithelia. Hear Res 139:97-115.

Garcia-Calvo M, Peterson EP, Leiting B, Ruel R, Nicholson DW, Thornberry NA (1998) Inhibition of human caspases by peptide-based and macromolecular inhibitors. J Biol Chem 273:32608-32613.

Garetz SL, Rhee DJ, Schacht J (1994) Sulfhydryl compounds and antioxidants inhibit cytotoxicity to outer hair cells of a gentamicin metabolite in vitro. Hear Res 77:75-80.

Hirose K, Hockenbery DM, Rubel EW (1997) Reactive oxygen species in chick hair cells after gentamicin exposure in vitro. Hear Res 104:1-14.

Hirose K, Westrum LE, Stone JS, Zirpel L, Rubel EW (1999) Dynamic studies of ototoxicity in mature avian auditory epithelium. Ann NY Acad Sci 884:389-409.

Kirsch DG, Doseff A, Chau BN, Lim DS, de Souza-Pinto NC, Hansford R, Kastan MB, Lazebnik YA, Hardwick JM (1999) Caspase-3dependent cleavage of Bcl-2 promotes release of cytochrome c. J Biol Chem 274:21155-21161.

Kothakota S, Azuma T, Reinhard C, Klippel A, Tang J, Chu K, McGarry TJ, Kirschner MW, Koths K, Kwiatkowski DJ, Williams LT (1997) Caspase-3-generated fragment of gelsolin: effector of morphological change in apoptosis. Science 278:294-298.

Lang H, Liu C (1997) Apoptosis and hair cell degeneration in the vestibular sensory epithelia of the guinea pig following a gentamicin insult. Hear Res 111:177-184.

Lazebnik YA, Kaufmann SH, Desnoyers S, Poirier GG, Earnshaw WC (1994) Cleavage of poly(ADP-ribose) polymerase by a proteinase with properties like ICE. Nature 371:346-347.

Li H, Zhu H, Xu CJ, Yuan J (1998) Cleavage of BID by caspase 8 mediates the mitochondrial damage in the Fas pathway of apoptosis. Cell 94:491-501.

Li L, Nevill G, Forge A (1995) Two modes of hair cell loss from the vestibular sensory epithelia of the guinea pig inner ear. J Comp Neurol 355:405-417.

Li P, Nijhawan D, Budihardjo I, Srinivasula SM, Ahmad M, Alnemri ES, Wang X (1997) Cytochrome c and dATP-dependent formation of Apaf-1/caspase-9 complex initiates an apoptotic protease cascade. Cell 91:479-489.

Luo X, Budihardjo I, Zou H, Slaughter C, Wang X (1998) Bid, a Bcl2 interacting protein, mediates cytochrome c release from mitochondria in response to activation of cell surface death receptors. Cell 94:481-490

Matsui JI, Messana EP, Alosi JA, Roberson DW, Cotanche DA, Warchol ME (2002a) Hair cell survival following aminoglycoside treatment with caspase inhibitors in vivo. Abstracts of the Twenty-Fifth Annual Midwinter Research Meeting of the Association for Research in Otolaryngology. 25:261.

Matsui JI, Ogilvie JM, Warchol ME (2002b) Inhibition of caspases prevents ototoxic and ongoing hair cell death. J Neurosci 22:1218-1227.

Matsushita K, Wu Y, Qiu J, Lang-Lazdunski L, Hirt L, Waeber C, Hyman BT, Yuan J, Moskowitz MA (2000) Fas receptor and neuronal cell death after spinal cord ischemia. J Neurosci 20:6879-6887.

Muzio M, Stockwell BR, Stennicke HR, Salvesen GS, Dixit VM (1998) An induced proximity model for caspase-8 activation. J Biol Chem 273:2926-2930

Salvesen GS, Dixit VM (1997) Caspases: intracellular signaling by proteolysis. Cell 91:443-446.

Sha SH, Schacht J (1999) Stimulation of free radical formation by aminoglycoside antibiotics. Hear Res 128:112-118.

Sha SH, Taylor R, Forge A, Schacht J (2001) Differential vulnerability of basal and apical hair cells is based on intrinsic susceptibility to free radicals. Hear Res 155:1-8.

Sinswat P, Wu WJ, Sha SH, Schacht J (2000) Protection from ototoxicity of intraperitoneal gentamicin in guinea pig. Kidney Int 58:2525-2532.

Song BB, Schacht J (1996) Variable efficacy of radical scavengers and iron chelators to attenuate gentamicin ototoxicity in guinea pig in vivo. Hear Res 94:87-93.

Stefanis L, Park DS, Friedman WJ, Greene LA (1999) Caspasedependent and -independent death of camptothecin-treated embryonic cortical neurons. J Neurosci 19:6235-6247.

Stennicke HR, Salvesen GS (2000) Caspases: controlling intracellular signals by protease zymogen activation. Biochim Biophys Acta 1477:299-306.

Strasser A, O'Connor L, Dixit VM (2000) Apoptosis signaling. Annu Rev Biochem 69:217-245.

Takumida M, Anniko M (2001) Nitric oxide in guinea pig vestibular sensory cells following gentamicin exposure in vitro. Acta Otolaryngol 121:346-350.

Thornberry NA, Rano TA, Peterson EP, Rasper DM, Timkey T, GarciaCalvo M, Houtzager VM, Nordstrom PA, Roy S, Vaillancourt JP, Chapman KT, Nicholson DW (1997) A combinatorial approach defines specificities of members of the caspase family and granzyme B functional relationships established for key mediators of apoptosis. J Biol Chem 272:17907-17911.

Vago P, Humbert G, Lenoir M (1998) Amikacin intoxication induces apoptosis and cell proliferation in rat organ of Corti. NeuroReport 9:431-436.

Warchol ME (1999) Immune cytokines and dexamethasone influence sensory regeneration in the avian vestibular periphery. J Neurocytol 28:889-900.

Yuan J, Yankner BA (2000) Apoptosis in the nervous system. Nature 407:802-809.

Zhou P, Chou J, Olea RS, Yuan J, Wagner G (1999) Solution structure of Apaf-1 CARD and its interaction with caspase-9 CARD: a structural basis for specific adapter/caspase interaction. Proc Natl Acad Sci USA 96:11265-11270. 